\title{
Aeropalynological Investigation of the University of Ilorin, Ilorin, Nigeria
}

\section{ABDULLAHI-ALANAMU ABDULRAHAMAN ${ }^{1^{*}}$, ORITSETIMEYIN S. ARUOFOR ${ }^{1}$, TAOFIK GARUBA ${ }^{2}$, OPEYEMI SAHEED KOLAWOLE ${ }^{3}$, GANIYU S. OLAHAN ${ }^{2}$ FELIX A. OLADELE ${ }^{1}$}

\author{
${ }^{I}$ Applied plant Anatomy and wood Technology Laboratory, \\ Department of Plant Biology, University of Ilorin, Ilorin, Nigeria \\ ${ }^{2}$ Department of plant Biology, university of Ilorin, Ilorin, Nigeria \\ ${ }^{3}$ Department of Biological Sciences, Faculty of Science, Federal University, Kashere, Gombe State, Nigeria \\ ; aaaoacademics@rocketmail.com; +2348033897870
}

KEYWORDS: Hey fever, meteorological parameters, pollens, spores, climate, University of Ilorin

\begin{abstract}
Hay fever allergy could either be from pollen or fungi spores. Using the Hirst model of pollen trap, pollen buckets were constructed; with pollen trap solutions inside them, they were placed in specific locations in the University of Ilorin for four months (December 2012/January 2013 to March/April 2013). Using acetolysis reaction, pollens and spores were recovered from the trap solution and were analyzed and identified in the microscope. Pollen/spore were counted and compared with meteorological parameters i.e. rainfall, sunshine, wind speed, humidity, and temperature. It was observed that pollen/spore concentrations were influenced by these meteorological factors. Hence there is need for us to always determine the amount of these pollen/spore concentrations all year round as it will help to predict the vegetation of a given area as well as helping hay fever sufferers manage their allergies effectively. CJASEM
\end{abstract}

\section{$\underline{\text { http://dx.doi.org/10.4314/jasem.v19i1.7 }}$}

\section{Introduction}

Palynology is the study of dust, strew, sprinkle or particles that are strewn. A classic palynologist analyses particulate sample collected from air, water, or any deposits including sediments of any age. The condition and identification of those particles, organic and inorganic, give the palynologist clues to life, the environment and the energetic conditions that produced them. The term is sometimes narrowly used to refer to a subset of the discipline which is defined as "the study of microscopic objects of macromolecular organic composition (i.e. compounds of carbon, hydrogen, nitrogen and oxygen), not capable of dissolution in hydrochloric or hydrofluoric acids (Sarjeant 2002). The study of these particulates in the air is referred to as aeropalynology. In March 2010, a strange harmattan dust covered the whole of Nigeria and raised issues bordering on changing weather conditions and its consequence on public health. Adeonipekun and John (2011) investigated this cream coloured dust and found out that pollen grains of Guinea/Sudan savanna vegetation species were dominant. This, together with the abundant diatom frustules recorded, further supports a Saharan desert source for the strange dust. Apart from the published work of Adekanmbi and Ogundipe (2010) in the southwest Nigeria and most recently Adeonipekun and John (2011), there is no other aeropalynological work in this area (Ilorin) to serve as a basis for aeropalynological study. Even the Adekanmbi and Ogundipe (2010) work only identified most of the recovered palynomorphs mainly to family level thus not creating the needed basic data for comparative pollen analysis. The work of Adeonipekun and John (2011) also was carried out on the dust deposited on a car bonnet over a month. The sample used was not directly collected from the air with an aerofloral sampler. However, in the southeast Nigeria, works of Agwu and Osibe (1992), Agwu (2001), Agwu et al. (2004), Njokuocha and Osayi (2005) and Njokuocha (2006) have created a rich data base for comparison and research in aeropalynology. These works have not only shown the richness of the aerospora, but have also provided basic data for the twelve months of the year in the Nsukka area as well as re-affirming also the contributions of allochthonous sources for the recovered aeropalynomorphs. The works of Adetunji et al. (1979) and Adedokun et al. (1989) on the mineralogy of harmattan dust in Nigeria have confirmed a Saharan source for the harmattan dust and affirmed its significance on the agriculture, health and micro-climate of West Africa and beyond.

Medical palynological and aeropalynological studies however are scarce in Nigeria and little or no known aeropollen data is available for the Ilorin metropolis. Thus the aim of this project research is to identify the concentrations of air borne pollen/fungal spores and the effect of some meteorological parameters in its concentration at the University of Ilorin, Ilorin, Nigeria. 


\section{MATERIALS AND METHODS}

Study areas: The study was carried out in four (4) selected areas at the University of Ilorin, Ilorin, Nigeria namely Jalala (Junior Staff Quarters), Senior Staff Quarters Unilorin Primary School and Unilorin secondary School.

Construction of pollen trap: A pollen trap was constructed consisting of the following, a four liter transparent bucket and a $25 \mathrm{~cm} \times 25 \mathrm{~cm}$ wire mesh. The bucket was filled with $175 \mathrm{~L}$ of water, $800 \mathrm{~mL}$ of formaldehyde, $14 \mathrm{~g}$ of phenol and $1.63 \mathrm{~L}$ of glycerol. The wire mesh was placed on top of the bucket and fastened with the aid of a wire.

The pollen trap was placed in a hole $30 \mathrm{~cm}$ deep at each sites of the study. The pollen trap was left for a month and was replaced with another pollen trap solution consecutively for a period of four months starting from December $7^{\text {th }} 2012$ to April $7^{\text {th }} 2013$. The recovered palynomorphs were identified after acetolysis reaction has being carried out on the pollen tap solution. Meteorological parameters data such as temperature, rainfall, wind speed, humidity, and sunshine were obtained from the Lower River Niger Basin, Ilorin station from the Meteorological and Hydrological Department from Dec 2012 - Apr 2013. The percentage abundance of the species and the monthly pollen/spore count were compared with the meteorological parameters and data.

Pollen and spore isolation and identification: Acetolysis reaction according to Erdtman (1960) destroys and extracts everything except for the extine, the highly resistant outer shell of the pollen that bears characteristic morphological features used in pollen identification. The extracted pollen was infiltrated with suitable mounting medium for light microscopy. This technique has been used for high resolution $3 \mathrm{D}$ imaging of the pollen.

All processing done in a $15 \mathrm{ml}$ polypropylene conical tube acetolysis reaction was done in the following steps: $6 \mathrm{ml}$ of suspended mixture of formaldehyde, phenol, water, and glycerol was obtained and poured in a centrifuge tube; $8 \mathrm{ml}$ of water was added to the suspended mixture. The mixture of water and suspension was shaken thoroughly, and centrifuged at 3000 revolutions per minute (rpm) for $15 \mathrm{~min}$. It was decanted and $10 \mathrm{ml}$ of Glacial Acetic acid was added. It was centrifuged for the second time at 3000rpm for $10 \mathrm{~min}$. Acetolysis mixture was prepared i.e. $9 \mathrm{ml}$ of acetic anhydride and $1 \mathrm{ml}$ of sulphuric acid. $5 \mathrm{ml}$ of this solution was added to the already decanted Glacial Acetic mixture, boiled for about 2 mins at 80- $90^{\circ} \mathrm{C}$. It was again centrifuged at $3000 \mathrm{rpm}$ for 10 mins. It was decanted and washed with distilled water three times; centrifuging at each interval of washing. The residue liquid was stored in the centrifuge tube for subsequent microscopic observations.

Microscopic Analysis: About 10-15 microliters of the washed acetolysed liquid was collected from tube using the micropipette. It was placed on a $25.4 \times 76.2 \mathrm{~mm}$ microscopic slide. A mountant was added to it to prevent easy dry up of the liquid. Mountant used was glycerol. The cover slide was placed on top of the liquid on the slide. A nail polish was used to seal the edges of the coverslip so as to prevent loss of sample liquid as a result of rapid dry out of the liquid. Thirty-two slides were prepared for each month of study and were viewed under the optical light microscope and were later identified.

Statistical Analysis: All the data gotten were reported and analyzed using Analysis of Variance (ANOVA) and Duncan's Multiple Range Test (DMRT). The computer software package SPSS 16.0 for windows was used for this analysis. The probability value of 0.05 was used as a bench mark for significant difference between the parameters.

\section{RESULTS}

The December/January microscopic analysis reveals total pollen/spore count of 277 belonging to 20 plant families and four fungi families with family Apocynaceae being the most dominant and Aspergillus spp being the most dominant in the fungi families. Other plant families were found in lower amount in the atmosphere. These include families like Cyperaceae, Fabaceae, Poaceae, Liliaceae, Orchindaceae, Alismataceae, Lentibulariaceae, Holaragacea etc. Four species of the fungal family were also identified and these includes; Aspergillus, Penicillium, Cladiosporium and Alternaria (Table 1).

In the January/Feburary microscopic analysis a total spore and pollen count of 340 were identified and these belong to19 plant families and three fungi families; namely Trichocomaceae, Davidellaceae, and Pleospoaraceae of which the Caldiosporium spp was the most dominant spore. The most dominant plant family was the Poaceae family, followed by the Polypodiaceae, Solanaceae and Cyperaceae families. Other families include the Brassicaceae, Annonaceae, Commelinaceae, and the Orchidaceae families (Table 2). 
Table 1: Pollen and spore analysis in December 2012 and January 2013 for Jalala area of the University of Ilorin, Ilorin, Nigeria

\begin{tabular}{|c|c|c|c|c|}
\hline $\mathbf{S} / \mathbf{N}$ & Scientific name & Family & $\begin{array}{l}\text { Nature of } \\
\text { pollen aperture }\end{array}$ & $\begin{array}{c}\text { Frequency of } \\
\text { pollen/spore }\end{array}$ \\
\hline 1 & Celosia argentia & Amaranthaceae & Periporate & 2 \\
\hline 2 & Desmodium paniculatum & Fabaceae & Tricolpate & 2 \\
\hline 3 & Asystasia gagentica & Acanthaceae & Tricolporate & 5 \\
\hline 4 & Phlebodium aurebum & Polypodiaceae & Monolete & 1 \\
\hline 5 & Utricularia foliosa & Lentibulariaceae & Polycolporoidate & 1 \\
\hline 6 & Taxodium distichum & Taxodiaceae & Monoporate & 10 \\
\hline 7 & Alstonia boonei (de wild) & Apocynaceae & Tricolporate & 7 \\
\hline 8 & Salvinia minima & Salviniaceae & Trilete & 2 \\
\hline 9 & Physalis pubescens & Solanaceae & Tricolporate & 1 \\
\hline 10 & Phoenix reclinata & Aracaceae(palmae) & Monosulcate & 8 \\
\hline 11 & Solanum americanum & Solanaceae & $\begin{array}{l}\text { Tricolporate- } \\
\text { syncolporate }\end{array}$ & 3 \\
\hline 12 & Gomphrena celosioides & Amaranthaceae & Inaperturate & 1 \\
\hline 13 & Asystasia vogeliana & Acanthaceae & Tricolporate & 2 \\
\hline 14 & Cladium mariseus & Cyperaceae & Ulcerate & 2 \\
\hline 15 & Sagittaria latifolia & Alismataceae & Ulcerate & 1 \\
\hline 16 & Sabal palmetto & Arecaceae & Monosulcate & 7 \\
\hline 17 & Eragrostis elliottis & Poaceae(Graminea) & Monoporate & 5 \\
\hline 18 & Sagittaria lancifolia & Alismataceae & Ulcerate & 1 \\
\hline 19 & Crinum americanum & Liliaceae & Monosulcate & 3 \\
\hline 20 & Alternanthera spp & Amaranthaceae & Inaperturate & 1 \\
\hline 21 & Thevetia neriifolia & Apocynaceae & Tricolporate & 7 \\
\hline 22 & Justicia elegantusa & Acanthaceae & Diporate & 9 \\
\hline 23 & Allamanda cathartica & Apocynaceae & Tricolporate & 5 \\
\hline 24 & Saururus cernuus & Saururaceae & Monosulcate & 8 \\
\hline 25 & Schinus terebinthifolius & Anacardiaceae & Tricolporate & 4 \\
\hline 26 & Trichopilia maculate & Orchindaceae & Inaperturate & 1 \\
\hline 27 & Justicia pectoralis & Acanthaceae & Diporate & 3 \\
\hline 28 & Astrocaryum standleyanum & Palmae & Panporate & 6 \\
\hline 29 & Onicidium ampliatum & Orchidaceae & Inaperturate & 1 \\
\hline 30 & Aritolochia pilosa & Apocynaceae & Tricolporate & 7 \\
\hline 31 & Meschites trifida & Apocynaceae & Inaperturate & 1 \\
\hline 32 & Chamaedorea wenlandiana & Aracaceae & Trilete & 5 \\
\hline 33 & Pennicilium spp & Trichocomaceae & Fungal spore & 36 \\
\hline 34 & Aspergillus spp & Trichocomaceae & Fungal spore & 26 \\
\hline 35 & Alternaria spp & Pleosporaceae & Fungal spore & 21 \\
\hline 36 & Cladosporium spp & Davidellaceae & Fungal spore & 38 \\
\hline 37 & Undefined spores & - & - & 38 \\
\hline
\end{tabular}

However the February/March 2013 microscopic analysis reveals a slight difference in the pollen, fungal spores (palynomorphs) in the atmosphere. Although persistent families like the Poaceae, Fabaceae, and the Taxodiaceae were present in the atmosphere, however there was a slow fall in their concentrations. The most dominant family was the Cyperaceae. In total, 12 families of plant species and 4 Fungi families were identified. A total of 229 spore/pollen count was recorded (Table 3 ).
Finally in the March/April 2013 results, pollen/spore concentrations in the atmosphere decrease significantly. Eight plant families and 4 fungal species were identified. A total pollen/spore count was 234 with Cyperaceae being the most dominant in the plant family and Pleosporaceae family being the dominant fungal spore (Table 4). 
Table 2: Pollen and spore analysis in January and February 2013 for Jalala area of the University of Ilorin, Ilorin, Nigeria

\begin{tabular}{|c|c|c|c|c|}
\hline $\mathbf{S} / \mathbf{N}$ & Scientific name & Family & $\begin{array}{l}\text { Nature of pollen } \\
\text { aperture }\end{array}$ & $\begin{array}{l}\text { Frequency of } \\
\text { pollen/spore }\end{array}$ \\
\hline 1 & Allamanda cathartica & Apocynaceae & Periporate & 3 \\
\hline 2 & Asystasia vogeliana & Acanthaceae & Tricolporate & 5 \\
\hline 3 & Tournefortia angustiflora & Boraginaceae & Trilete & 2 \\
\hline 4 & Diplazium grandifolium & Polypodiaceae & Monocolporate & 6 \\
\hline 5 & Cassia obtusifolia & Fabaceae & Tricolporoidate & 9 \\
\hline 6 & Eleocharis cellulose & Cyperaceae & Ulcerate & 7 \\
\hline 7 & Axonopus compressus & Cyperaceae & Monoporate & 19 \\
\hline 8 & Coryanthes manculata & Orchidaceae & Inaperturate & 8 \\
\hline 9 & Anacardium occidentalis & Acanthaceae & Tricolporate & 9 \\
\hline 10 & Mormodes unlata & Orchidaceae & Aporate & 6 \\
\hline 11 & Rhynchospora cephalotes & Commelinaceae & Monocolpate & 9 \\
\hline 12 & Matelea trianae & Asclepiadaceae & Vesculate & 5 \\
\hline 13 & Sagittaria latifolia & Alismataceae & Ulcerate & 2 \\
\hline 14 & Commelina diffusa & Commelinaceae & Monosulcate & 4 \\
\hline 15 & Saururus cernuus & Saururaceae & Monosulcate & 3 \\
\hline 16 & Thelypetris balbis & Polypodiaceae & Monolete & 22 \\
\hline 17 & Trichomanes godmanii & Cyantheaceae & Trilete & 7 \\
\hline 18 & Descurainta pinnata & Brassicaceae & Trilete & 8 \\
\hline 19 & Solanum americanum & Solanaceae & $\begin{array}{l}\text { Tricolporate- } \\
\text { syncolporate }\end{array}$ & 3 \\
\hline 20 & Aritolochia pilosa & Rubiaceae & Tricolporate & 20 \\
\hline 21 & Ichanthus pallens & Poaceae & Monoporate & 9 \\
\hline 22 & Orthoclada laxa & Poaceae & Monoporate & 13 \\
\hline 23 & Paspalidium paniculatum & Poaceae & Monoporate & 9 \\
\hline 24 & Leptochloa virgate & Poaceae & Monoporate & 5 \\
\hline 25 & Lasiacis procerrima & Poaceae & Monoporate & 6 \\
\hline 26 & Paspalum conjugatum & Poaceae & Monoporate & 5 \\
\hline 27 & Acer rubrum & Aceraceae & Inaperturate & 7 \\
\hline 28 & Thelypteris incise & Polypodiaceae & Monolete & 4 \\
\hline 29 & Capsicum аппиит & Solanaceae & Inaperturate & 2 \\
\hline 30 & Geonoma procumbens & Aceraceae & Trilete & 9 \\
\hline 31 & Aspidosperma cruenta & Apocynaceae & Syncolporate & 8 \\
\hline 32 & Desmopsis panamensis & Annonaceace & Inaperturate & 4 \\
\hline 33 & Alternaria spp & Pleosporaceae & Fungal spore & 27 \\
\hline 34 & Caldosprium spp & Davidellaceae & Fungal spore & 29 \\
\hline 35 & Aspergillus spp & Trichocomaceae & Fungal spore & 13 \\
\hline 36 & Penicillium spp & Trichocomaceae & Fungal spore & 10 \\
\hline 37 & Undefined spores & - & - & 35 \\
\hline
\end{tabular}


Table 3: Pollen and spore analysis in February/March 2013 for Jalala area of the University of Ilorin, Ilorin, Nigeria

\begin{tabular}{lllll}
\hline S/N & Scientific name & Family & $\begin{array}{l}\text { Nature of } \\
\text { pollen aperture }\end{array}$ & $\begin{array}{c}\text { Frequency of } \\
\text { pollen/spore }\end{array}$ \\
\hline $\mathbf{1}$ & Scetaria parviflora & Poaceae & Monoporate & 7 \\
$\mathbf{2}$ & Cladium mariscus & Cyperaceae & Ulcerate & 5 \\
$\mathbf{3}$ & Eleocharis cellulocosa & Cyperaceae & Ulcerate & 3 \\
$\mathbf{4}$ & Acrostichum danaeiflolium & Pterdiaceae & Trilete & 15 \\
$\mathbf{5}$ & Taxodium distichum & Taxodiaceae & Monolete & 11 \\
$\mathbf{6}$ & Phlebodium aureum & Polypodiaceae & Monolete & 2 \\
$\mathbf{7}$ & Cyerus haspan & Cyeraceae & Ulcerate & 1 \\
$\mathbf{8}$ & Boehmeria cylindrica & Urticaceae & Diporate & 34 \\
$\mathbf{9}$ & Typha latifolia & Typhaceae & Monoulcerate & 4 \\
$\mathbf{1 0}$ & Thelypteris kunthii & Thelypteridaceae & Monolete & 6 \\
$\mathbf{1 1}$ & Schoenoplectus & Cyperaceae & Ulcerate & 10 \\
& taberaeamontani & & & 27 \\
$\mathbf{1 2}$ & Vigna luteola & Fabaceae & Triporate & 1 \\
$\mathbf{1 3}$ & Rhychospora colorata & Cyperaceae & Syncolporate & 2 \\
$\mathbf{1 4}$ & Morella cerifera & Myricaceae & Ulcerate & 2 \\
$\mathbf{1 5}$ & Myriophyllum spp & Holaragaceae & Stephanoporate & 1 \\
$\mathbf{1 6}$ & Phragmites australis & Poaceae & Monoporate & 4 \\
$\mathbf{1 7}$ & Ilex cassine & Aquifoliaceae & tricolporate & 15 \\
$\mathbf{1 8}$ & Caladosporium & Davidellaceae & Fugal spore & 10 \\
$\mathbf{1 9}$ & Aspergillus spp & Trichocomaceae & Fugal spore & 18 \\
$\mathbf{2 0}$ & Penicillum spp & Trichocomaceae & Fugal spore & 17 \\
$\mathbf{2 1}$ & Alternaria spp & Pleosporaceae & Fugal spore & 43 \\
$\mathbf{2 2}$ & Undefined spores & & & \\
\hline & & & & \\
& & & & 15 \\
\end{tabular}

Table 4: Pollen and spore analysis in March/April 2013 for Jalala area of the University of Ilorin, Nigeria

\begin{tabular}{lllll}
\hline $\mathbf{S} / \mathbf{N}$ & Scientific name & Family & $\begin{array}{l}\text { Nature of } \\
\text { pollen aperture }\end{array}$ & $\begin{array}{l}\text { Frequency of } \\
\text { pollen/spore }\end{array}$ \\
\hline $\mathbf{1}$ & & & Monoporate & 21 \\
$\mathbf{2}$ & Axonopus compressus & Cyperaceae & Ulcerate & 4 \\
$\mathbf{3}$ & Eleocharis cellulose & Cyperaceae & Triclporate & 10 \\
$\mathbf{4}$ & Cassia obtusifolia & Fabaceae & Periporate & 3 \\
$\mathbf{5}$ & Alamanda catherica & Apocynaceae & Trilete & 3 \\
$\mathbf{6}$ & Maurnefortia grandifolium & Boraginaceae & Vesulate & 1 \\
$\mathbf{7}$ & Commelina diffusa & Ascelpiadiacea & Tricolporate & 7 \\
$\mathbf{8}$ & Rhynchospora cephalotes & Commelinaceae & Monoporate & 5 \\
$\mathbf{9}$ & Sagittaria latifolia & Alismataceae & Ulcerate & 9 \\
$\mathbf{1 0}$ & Asystatia gagentica & Acanthaceae & Tricolporate & 9 \\
$\mathbf{1 1}$ & Alstonia boonei & Apocynaceae & Tricolporate & 17 \\
$\mathbf{1 2}$ & Utricularia foliosa & Lentibulariaceae & Polycolporate & 1 \\
$\mathbf{1 3}$ & Phoenix reclinata & Aracaceae & Monosulcate & 5 \\
$\mathbf{1 4}$ & Justicia petoralis & Acanthaceae & Diporate & 5 \\
$\mathbf{1 5}$ & Celosia argentia & Amaranthaceae & Periporate & 9 \\
$\mathbf{1 6}$ & Cladium mariseus & Cyperaceae & Ulcerate & 3 \\
$\mathbf{1 7}$ & Salvinia minima & Salvinaceae & Periporate & 3 \\
& & & & \\
$\mathbf{1 8}$ & Boehmeria cylindrical & Utricaceae & Diporate & 17 \\
$\mathbf{1 9}$ & Alternaria spp & Pleosporaceae & Fugal spore & 11 \\
$\mathbf{2 0}$ & Cladosporium spp & Davidiellaceae & Fugal spore & 29 \\
$\mathbf{2 1}$ & Aspergillus spp & Trichocomaceae & Fungal spore & 7 \\
$\mathbf{2 2}$ & Undefined spores & & & 21 \\
$\mathbf{2 3}$ & Aritolochia pilosa & Apocyanceae & Monolete & 15 \\
\hline & & & & \\
\hline
\end{tabular}

\section{DISCUSSION}

The suspension of pollen grains in the atmosphere is a phenomenon that is inherent to the biological function of these particles, since the wind is the major mode of transportation of the pollens and spores of most flowering plants and fungi. It carries the grains from the anthers to the stigma of unisexual flowers, facilitating pollination (Charlesworth 1993) and often the pollen grains of these plants undergo various modifications (Crane 1986). One indirect consequence of this airborne transport is the appearance of allergic reactions in humans when pollen/fungi spore is inhaled and its proteins are released thereby forming antigens to which the immune system reacts, provoking allergic symptoms. As in many other biological processes, pollen/fungi spore dispersal is influenced by meteorological parameters like rainfall, sunshine, temperature and relative humidity. These may determine the timing of the flowering season and release of fungi spores by way of photoperiod, the rate of maturation of conidia, as well as the development of flower organs via their physiology, or by affecting the dynamics of the air 
which the pollens and spores travel as passive elements (Ligthart et al. 1979; Benningnoff 1987).

From the results of this work, spore/pollen count and identification was recorded for the four month period of the study; in all pollen and spore count was most abundant in the Jan/Feb month of the analysis. Spore/pollen count values showed significant correlation with the meteorological parameters. Positive and statistically significant correlation was found between pollen/spore count and the mean temperature ( $\min$ and $\max$ ) of the months, wind speed, rainfall and sunshine while negative correlation was observed between the mean relative humidity and pollen/spore count. The amount of sunshine, rain or wind speed affects how much pollen/spore is released and how much the pollen/spore is spread around. On humid day, pollen/spore spreads slowly, during windy days, pollen/spore are transported over long distances (Gregory 1978). Wind speed is therefore recognized as being the most important factor (McDonald 1980). On rainy days, pollen may be cleared from the air, causing pollen levels to fall. People suffering from pollen and spore allergies look out for the counts whether daily or monthly concentrations to help them start and plan their day (McDonald 1980). The pollen/spore count tells us the amount of pollen in a certain sample of air in a given area.

In the Dec/Jan pollen/spore count, it was noted that pollen dispersal and concentration were not as dense as in the Jan/Feb pollen/spore count. This was attributed to the cold weather as we know anthesis occurs usually in the warm weather hence pollen dispersal was not very effective due to low temperature of the atmosphere. But the fungi spores where much more in abundance, that is to say the cold weather was not much of a factor in the dispersal of these fungi spores because most of these spores are produced from decaying organic matter. In line with this, most of the fungi spores identified are mostly parasitic. For example Aspergillus spp are a major cause of decay of agricultural crops in the field and in storage, and many species are also common in contaminated indoor environments. The Cladiosporium spp were found to be the most abundant of the entire fungi spore present. This is to say that mean temperature of $17.45^{\circ} \mathrm{C}$ and $33.42^{\circ} \mathrm{C}$ for both the minimum and maximum has an effect on the dispersal of pollen and not really significant in the dispersal of fungi spores. Also the amount of rainfall for Dec/Jan was very low with a total of $7.2 \mathrm{~mm}$ hence pollen/spore dispersal was not inhibited by rainfall due to the relative concentrations of spores in the atmosphere. The relative humidity also played a role in the dispersal of spore having wet and dry humidity mean values of $17.97 \%$ and $19.22 \%$ respectively. One can say that pollen dispersal was affected indirectly in the airspora due to loss of water in the anther cell walls that facilitates anther mechanical breakage which releases the pollen (Nitius 2004). The moderate mean wind speed of $80.25 \mathrm{~km} / \mathrm{h}$ for the month of Dec/Jan explains the dispersal and concentration of spores better than all other meteorological parameters. At moderate wind speed, the pollen count in the atmosphere does not decrease, almost to an altitude of $1,000 \mathrm{~m}$. According to Nitius (2004) during the day, when the cloud of pollen is brought up by the convection currents, no selection of pollen grains according to their size and mass takes place, but during the night, especially on a quiet one, larger and heavier grains descend significantly faster than smaller ones reducing the pollen concentration in the atmosphere. The wind is the passive fluid in which pollen and spores travel as passive elements (Ligthart et al. 1979; Benningnoff 1987). The relative high wind speed for the Dec/Jan period of study ensure the dispersal of the spores hence even though the temperature was relatively low there was still enough pollen to cause harm to hay fever suffers.

The Jan/Feb spore count was the highest record of 340 in the period of study. A mean minimum and max temperature of $20.42^{\circ} \mathrm{C}$ and $34.23^{\circ} \mathrm{C}$ respectively has no much significance on the pollen/spore distribution during the Dec/Jan period of study as pollen were in much denser concentrations than the fungi spores. The most dominant pollen was from the Poaceae family. The Cladosporium spp of the fungi spore was also in abundance but in lesser amounts as compared to the previous month of study. The increase in rainfall value can be infer to have reduced the concentration of the fungi spore as the rain cleanses the air but that is just an assumption however the mean sunshine hour of $6 \mathrm{hrs} 50 \mathrm{~min}$ might be responsible for the increased pollen spore concentrations due to the fact that most plants undergo anthesis (i.e. the opening of flowers) and release pollen early in the morning. As the day gets warmer and more flowers open, pollen levels rise. On sunny days, the pollen count is highest in the early evening. The effect of the humidity on anther opening is also another factor to look out in the pollen abundance of the Jan/Feb period having wet and dry percentage humidity of 19.42 and 20.41 respectively. This may be as a result of the loss of water i.e. dry humidity, tension on the cell walls increases, anthers break up and pollen is released (Nitius 2004). The high wind speed mean of $113.625 \mathrm{KM} / \mathrm{H}$ of the $\mathrm{Jan} / \mathrm{Feb}$ period of study is a major and more distinct factor of pollen/spore distribution. Fluctuations of pollen counts in the different locations of the Jala area of study may be affected by the grains brought from long dispersal and redisposition in the air currents.

The Feb/March period of study records the lowest amounts of spore count of 229. This could be as a 
result of the gradual change in the weather from the dry season to the early rainy season. Having a total rainfall of $40.7 \mathrm{~mm}$ which is much higher when compared to the previous months of the study, the air is said to have being relatively wash free of spores. The minimum and maximum temperature of $23.84^{\circ} \mathrm{C}$ and $35.52^{\circ} \mathrm{C}$ could not explain the drop in the pollen concentration. However moderate wind speed of $94.96 \mathrm{KM} / \mathrm{H}$ explained the reason why pollen/spore were still present although in moderate concentrations in the atmosphere. Wind current disperse pollen/spore randomly and at low speeds selects the pollen/spore. Heavier pollens/spores tend to fall back to the ground leaving only lighter ones in the air. The relative wet and dry humidity of $23.36 \%$ and $23.75 \%$ respectively could not explain pollen concentration drop due to the narrow significant differences at $\mathrm{p}<0.05$ or $\mathrm{p}=0.05$.

The March/April result revealed a total spore count value of 234. There is a slight increase in this value in spite of the high amounts of rainfall of $106.7 \mathrm{~mm}$. This increase could be inferred from the relatively high mean sunshine value of $7 \mathrm{hrs} 10 \mathrm{~min}$ which means flower opening was more due to the warm weather. The mean wind speed of $127.7 \mathrm{KM} / \mathrm{H}$ which is the highest so far encourages dispersal and redisposition of spores. The mean $\min$ and $\max$ temperature of $23.90 \mathrm{oC}$ and $34.90 \mathrm{oC}$ as well as the percentage wet and dry of humidity of $23.30 \%$ and $24.45 \%$ played no significant role in spore count increments.

Conclusion: From the microscopic and statistical analysis of meteorological effect on pollen/fungi spore in the atmosphere, one can say truly that pollen/spore concentration is influenced by wind speed, rainfall, sunshine, humidity and temperatures. Hence hay fever sufferers should note the amounts of these parameters; in so doing allergies can be effectively managed. Pollen counts alone are unlikely to give an accurate indication of health risks for allergy or asthma sufferers, as pollen potency can vary widely. Hay fever sufferers can become sensitized by other, less allergenic, pollen species in advance of the main pollen season, which may increase the severity of the allergic reaction.

The pollen forecast and pollen calendar (which shows when different types of plant pollen that cause allergic reactions are present in the environment) also involve expert judgment on, and provide information about, the specific allergenic pollen types in the area of interest. Pharmaceutical organizations often use these forecasts not only by displaying it on their website but also to predict demand and supply of medication, such as histamine antagonists (commonly known as antihistamines), which alleviate some of the hay fever symptoms.

Understanding the potential increase in the health burden in relation to allergy will help health organizations and clinicians to plan for the future. There are already significant costs to the economy relating to allergic rhinitis in loss of productivity and days off work. Understanding how this financial burden may increase in the future is another area of potential interest. Further studies that will cover the twelve (12) months and even years should be carried out in the future to account for a more broad coverage of the area in question

In the Jalala areas pollen count was done in four different locations during the four month period of study a summary of these location and the relative occurrences of spore is highlighted in the table below 
Table 5: Pollen and spore analysis for Primary School area

\begin{tabular}{|c|c|c|c|}
\hline $\mathbf{S} / \mathbf{N}$ & Scientific name & Family & $\begin{array}{l}\text { Frequency } \\
\text { pollen/spore }\end{array}$ \\
\hline 1 & Celosia argentia & Amaranthaceae & 3 \\
\hline 2 & Asystatia gagentica & Acanthaceae & 14 \\
\hline 3 & Utricularia foliosa & Lentibulariaceae & 1 \\
\hline 4 & Desmodium paniculatum & Fabaceae & 2 \\
\hline 5 & Taxodium distichum & Taxodiaceae & 7 \\
\hline 6 & Alternanthera spp & Amaranthaceae & 4 \\
\hline 7 & Cladium mariseus & Cyperaceae & 5 \\
\hline 8 & Crinum americanum & Liliaceae & 1 \\
\hline 9 & Eragrostis elliotis & Poaceae & 2 \\
\hline 10 & Sabal palmetto & Arecaceae & 3 \\
\hline 11 & Anacardium occidentalis & Acanthaceae & 3 \\
\hline 12 & Matelea trianae & Ascelpiadiaceae & 2 \\
\hline 13 & Justicia petoralis & Acanthaceae & 2 \\
\hline 14 & Aritolochia pilosa & Apocyanceae & 7 \\
\hline 15 & Acrostichum danaeifolium & Pteridiaceae & 15 \\
\hline 16 & Alamanda catherica & Apocynaceae & 5 \\
\hline 17 & Tournefortia angustiflora & Boraginaceae & 2 \\
\hline 18 & Cassia obtusifolia & Fabaceae & 7 \\
\hline 19 & Axonopus compressus & Cyperacea & 10 \\
\hline 20 & Thelypteris incise & Polypodiaceae & 1 \\
\hline 21 & Desmopsis panamensis & Annonaceae & 2 \\
\hline 22 & Leptochola virginata & Poaceae & 3 \\
\hline 23 & Lasiacis procerrima & Poaceae & 5 \\
\hline 24 & Geonoma procumbens & Aceraceae & 3 \\
\hline 25 & Phargmites australis & Poaceae & 6 \\
\hline 26 & Thelypteris kunthii & Thelypteridaceae & 6 \\
\hline 27 & Morella certifera & Myricaceae & 2 \\
\hline 28 & Phleobodium aureum & Polypodiaceae & 3 \\
\hline 29 & Cyperus haspan & Cyperaceae & 6 \\
\hline 30 & Coryanthes manculata & Orchidaceae & 4 \\
\hline 31 & Descurainta pinnata & Brassiceae & 5 \\
\hline 32 & Trichophilia manculata & Orchidaceae & 4 \\
\hline 33 & Thevitia neriifolia & Apocynaceae & 4 \\
\hline 34 & Chamaedorea wendlandiana & Arecaceae & 3 \\
\hline 35 & Osmudia regalis & Osmundaceae & 6 \\
\hline 36 & Justicia elegantusa & Acanthaceae & 5 \\
\hline 37 & Saururus cernuus & Saururaceae & 4 \\
\hline 38 & Cladosporuim spp & Davidiellaceae & 32 \\
\hline 39 & Alternaria spp & Pleosporaceae & 34 \\
\hline 40 & Undefined spores & & 45 \\
\hline
\end{tabular}

Table 6: Pollen and spore analysis for Secondary School

\begin{tabular}{|c|c|c|c|}
\hline $\mathbf{S} / \mathbf{N}$ & Scientific name & Family & $\begin{array}{l}\begin{array}{l}\text { Frequency } \\
\text { pollen/spore }\end{array} \\
\end{array}$ \\
\hline 1 & Alsotonia boonei & Apocynaceae & 10 \\
\hline 2 & Utricularia foliosa & Lentibulariaceae & 1 \\
\hline 3 & Phoenix reclinata & Arecaceae & 3 \\
\hline 4 & Gompherena celosioides & Amaranthaceae & 1 \\
\hline 5 & Rhynchospora cephalotes & Commelinaceae & 14 \\
\hline 6 & Axonopus compressus & Cyperaceae & 34 \\
\hline 7 & Eleocharis cellulose & Cyperaceae & 8 \\
\hline 8 & Cassia obtusifolia & Fabaceae & 6 \\
\hline 9 & Alamanda catherica & Apocynaceae & 2 \\
\hline 10 & Tournefortia grandifolium & Boraginaceae & 27 \\
\hline 11 & Matelea trianae & Ascelpiadiaceae & 4 \\
\hline 12 & Commelina diffusa & Commelinaceae & 3 \\
\hline 13 & Sagittaria latifolia & Alismataceae & 1 \\
\hline 14 & Taxodium distichum & Taxodiaceae & 11 \\
\hline 15 & Alternanthera spp & Amaranthaceae & 3 \\
\hline 16 & Cladium mariseus & Cyperaceae & 2 \\
\hline 17 & Crinum americanum & Liliaceae & 2 \\
\hline 18 & Eragrostis elliotis & Poaceae & 6 \\
\hline 19 & Sabal palmetto & Arecaceae & 9 \\
\hline 20 & Anacardium occidentalis & Acanthaceae & 3 \\
\hline 21 & Thelypteris balisis & Polypodiaceae & 4 \\
\hline 22 & Justicia petoralis & Acanthaceae & 2 \\
\hline 23 & Phleobodium aureum & Polypodiaceae & 4 \\
\hline 24 & Alternaria spp & Pleosporaceae & 10 \\
\hline 25 & Cladosprium spp & Davidellaceae & 35 \\
\hline 26 & Aspergillus spp & Trichocomaceae & 10 \\
\hline 27 & Penicillium & Trichocomaceae & 18 \\
\hline 28 & Undefined spores & & 34 \\
\hline
\end{tabular}


From the result of the analysis of variance carried out

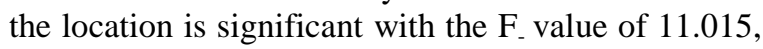
at 0.05 alpha level of significance, we reject the null hypothesis and conclude that there is a significant difference in pollen count across the locations in each month. The analysis also indicated that there is significant difference in the pollen count collected with F_value of 8.416, 0.05 alpha level of significance in the months.

Also the analysis of variance (ANOVA), there is significant difference in the effect of the metrological parameters namely humidity (dry and wet), temperature (min. and max.), rainfall, sunshine and wind speed on the amount of pollen count.

Table 7: Pollen and spore analysis for Junior Staff Quarters

\begin{tabular}{|c|c|c|c|}
\hline $\mathbf{S} / \mathbf{N}$ & Scientific name & Family & $\begin{array}{l}\text { Frequency } \\
\text { of occurrence }\end{array}$ \\
\hline 1 & Lasiacis procerrima & Poaceae & 1 \\
\hline 2 & Geonoma procumbens & Aceraceae & 6 \\
\hline 3 & Phargmites australis & Poaceae & 2 \\
\hline 4 & Celosia argentia & Amaranthaceae & 8 \\
\hline 5 & Mormodes unlata & Orchidaceae & 2 \\
\hline 6 & Salvinia minima & Salvinaceae & 3 \\
\hline 7 & Boehimeria cylindrical & Utricaceae & 7 \\
\hline 8 & Desmopsis panamensis & Annonaceae & 1 \\
\hline 9 & Osmudia regalis & Osmundaceae & 9 \\
\hline 10 & Justicia elegantusa & Acanthaceae & 14 \\
\hline 11 & Saururus cernuus & Saururaceae & 2 \\
\hline 13 & Justicia petoralis & Acanthaceae & 2 \\
\hline 14 & Aritolochia pilosa & Rubiaceae & 27 \\
\hline 15 & Ichanthus pallens & Poaceae & 9 \\
\hline 16 & Orthoclada laxa & Poaceae & 6 \\
\hline 17 & Paspalidium paniculatum & Poaceae & 9 \\
\hline 18 & Leptochloa virgate & Poaceae & 2 \\
\hline 19 & Aspidosperma cruenta & Apocynaceae & 6 \\
\hline 20 & Paspalum conjugatum & Poaceae & 6 \\
\hline 21 & Acer rubrum & Aceraceae & 7 \\
\hline 22 & Thelypteris incise & Polypodiaceae & 3 \\
\hline 23 & Capsicum annuum & Solanaceae & 3 \\
\hline 24 & Cyperus haspan & Cyperaceae & 17 \\
\hline 25 & Coryanthes manculata & Orchidaceae & 2 \\
\hline 26 & Descurainta pinnata & Brassiceae & 2 \\
\hline 27 & Trichophilia manculata & Orchidaceae & 4 \\
\hline 28 & Thevitia neriifolia & Apocynaceae & 3 \\
\hline 29 & $\begin{array}{l}\text { Chamaedorea } \\
\text { wendlandiana }\end{array}$ & Arecaceae & 2 \\
\hline 30 & Desmopsis panamensis & Annonaceae & 11 \\
\hline 31 & Aritolochia pilosa & Apocyanceae & 8 \\
\hline 32 & Phargmites australis & Poaceae & 3 \\
\hline 33 & Celosia argentia & Amaranthaceae & 3 \\
\hline 34 & Mormodes unlata & Orchidaceae & 4 \\
\hline 35 & Axonopus compressus & Cyperaceae & I6 \\
\hline 36 & Sagittaria latifolia & Alismataceae & 1 \\
\hline 37 & Diplazium grandifolium & Polypodiaceae & 6 \\
\hline 38 & Coryanthes manculata & Orchidaceae & 2 \\
\hline 39 & Descurainta pinnata & Brassicaceae & 1 \\
\hline 40 & Alamanda catherica & Apocynaceae & 1 \\
\hline 41 & Anacardium occidentalis & Acanthaceae & 3 \\
\hline 42 & Trichomanes godmanii & Cyntheaceae & 4 \\
\hline 43 & $\begin{array}{l}\text { Shoenoplectus } \\
\text { tabaraemontani }\end{array}$ & Cyperaceae & 3 \\
\hline 44 & Rhynospora colorata & Cyperaceae & 3 \\
\hline 45 & Myriophyllum spp & Holaragaceae & 8 \\
\hline 46 & Alternaria spp & Pleosporaceae & 11 \\
\hline 47 & Caldosprium spp & Davidellaceae & 35 \\
\hline 48 & Aspergillus spp & Trichocomaceae & 17 \\
\hline 49 & Penicillium & Trichocomaceae & 10 \\
\hline 50 & Undefined spores & & 27 \\
\hline
\end{tabular}


Table 8: Pollen and spore analysis for Senior Staff Quarters

\begin{tabular}{|c|c|c|c|}
\hline $\mathbf{S} / \mathbf{N}$ & Scientific name & Family & $\begin{array}{l}\text { Frequency } \\
\text { of pollen/spore }\end{array}$ \\
\hline 1 & Alamanda catherica & Apocynaceae & 3 \\
\hline 2 & Asyastasia vogeliana & Acanthaceae & 7 \\
\hline 3 & Tournefortia gandifolium & Boraginacea & 1 \\
\hline 4 & Cassia obtusifolia & Fabaceae & 6 \\
\hline 5 & Eleocharis cellulose & Cyperaceae & 10 \\
\hline 6 & Commelina diffusa & Commelinaceae & 8 \\
\hline 7 & Trichomanes godmanii & Cyatheceaceae & 3 \\
\hline 8 & Thelypteris balbis & Polypodiaceae & 4 \\
\hline 9 & Solanum americanum & Solanaceae & 10 \\
\hline 10 & Aspidosperma cruenta & Apocynaceae & 2 \\
\hline 11 & Paspalum conjugatum & Poaceae & 2 \\
\hline 12 & Celosia argentia & Amarantaceae & 15 \\
\hline 13 & Geonoma procumbens & Aceraceae & 3 \\
\hline 14 & Leptochloa virgate & Poaceae & 1 \\
\hline 15 & Orthoclada laxa & Poaceae & 7 \\
\hline 16 & Boehimeria cylindica & Utricaceae & 18 \\
\hline 17 & Ilex cassine & Aquifoliaceae & 4 \\
\hline 18 & Osmudia regalis & Osmudaceae & 3 \\
\hline 19 & Alstonia boonei & Apocynaceae & 14 \\
\hline 20 & Salvinia minima & Salvinaceae & 2 \\
\hline 21 & Saururus cernuиs & Saururacaea & 4 \\
\hline 22 & Schinus terebinthifolius & Anacardiaceae & 4 \\
\hline 23 & Justicia petoralis & Acanthaceae & 2 \\
\hline 24 & Phoenix reclinata & Aracaceae & 4 \\
\hline 25 & Onicidium amplicatum & Orchidaceae & 7 \\
\hline 26 & Sagittaria latifolia & Alismataceae & 1 \\
\hline 27 & Sabal palmetto & Arecaceae & 2 \\
\hline 28 & Cladium mariseus & Cyperaceae & 3 \\
\hline 29 & Taxodium distichum & Taxodiaceae & 3 \\
\hline 30 & Alternanthera spp & Amarantaceae & 2 \\
\hline 31 & Alternaria spp & Pleosporaceae & 8 \\
\hline 32 & Caldosprium spp & Davidellaceae & 17 \\
\hline 33 & Aspergillus spp & Trichocomaceae & 26 \\
\hline 34 & Penicillium & Trichocomaceae & 16 \\
\hline 35 & Undefined spores & & 30 \\
\hline
\end{tabular}

Table 9: Monthly effects of meteriological parameters on aeropalynomorphs concentration

\begin{tabular}{|c|c|c|c|c|c|c|c|}
\hline Month & $\begin{array}{l}\text { Dry } \\
\text { humidity }\end{array}$ & $\begin{array}{l}\text { Wet } \\
\text { humidity }\end{array}$ & $\begin{array}{l}\text { Minimum } \\
\text { temperature }\end{array}$ & $\begin{array}{l}\text { Maximum } \\
\text { temperature }\end{array}$ & Rainfall & Sunshine & Wind speed \\
\hline Dec. 2012 - Jan. 2013 & $19.2258^{\mathrm{a}}$ & $17.9677^{\mathrm{a}}$ & $17.4516^{\mathrm{a}}$ & $33.4194^{\mathrm{a}}$ & $7.7000^{b}$ & $8.2000^{\mathrm{c}}$ & $41.4194^{\mathrm{a}}$ \\
\hline Jan-Feb 2013 & $20.4194^{b}$ & $19.4135^{\mathrm{b}}$ & $20.4194^{\mathrm{b}}$ & $34.2258^{\mathrm{b}}$ & $1.4000^{\mathrm{a}}$ & $6.9000^{\mathrm{a}}$ & $56.6452^{\mathrm{b}}$ \\
\hline Feb-Mar 2013 & $23.7500^{\mathrm{c}}$ & $23.3571^{\mathrm{c}}$ & $23.8381^{\mathrm{c}}$ & $35.5161^{\mathrm{d}}$ & $40.7000^{c}$ & $6.7732^{\mathrm{a}}$ & $95.0000^{c}$ \\
\hline Mar-Apr 2013 & $24.4516^{\mathrm{d}}$ & $23.2903^{c}$ & $23.9032^{\mathrm{c}}$ & $34.9032^{c}$ & $1.0670 \mathrm{E} 2^{\mathrm{d}}$ & $7.1339^{\mathrm{b}}$ & $127.7097^{\mathrm{d}}$ \\
\hline Total & 21.9617 & 21.0072 & 21.4031 & 34.5161 & 39.1250 & 7.2518 & 80.1936 \\
\hline
\end{tabular}

There is significant difference in the values of means in the column not followed by the same superscript

\section{REFERENCES}

Adedokun, J. A., Emofurieta, W. O., Adedeji, O. A. 1989. Physical mineralogical and chemical properties of harmattan dust at Ile-Ife, Nigeria. Theor. Appl. Climatol. 40: $161-169$.

Adekanmbi, O., Ogundipe, O. 2010. Aeropalynological studies of the University of Lagos campus, Nigeria. Notulae Scientia Biologicae 2(4):34-39.

Adeonipekun, P. A., John, M. 2011. Palynological Investigation of Haze Dust in Ayetoro-Itele Ota, Southwest Nigeria. J. Ecol. Nat. Environ., 3(14):455460

Adetunji, J., Mcgregor J., Ong, C. K. 1979. The harmattan haze. Weather J. 34:430-436.
Agwu, C. O. C. 2001. A study of Niger Delta environment through airborne palynomorphs, Port Harcourt, Nigeria. Palaeoecol. Afr., 27:191-205.

Agwu, C. O. C., Njokuacha, R. C., Mezue, O. 2004. The study of airborne pollen and spores circulating at "Head Level" in Nsukka environment. Bio-Res., 2(2): 7-14.

Agwu, C. O. C., Osibe, E. E. 1992. Airborne palynomorphs of Nsukka during the months of February - April, 1990. Niger. J. Bot., 5: 177-185

Altinta, D. U., Karakoc, G. B., Yilmaz, M., Pinar, M., Kendirli, S. G., Cakan, H. 2004. The relationship between pollen counts and weather variables in East Mediterranean Coast of Turkey. Development Immunology 2:87-37. 
Anderson, S. T. 1980. Influence of climatic variation on pollen season severity in wind pollinated trees and herbs. Grana 19:47-52.

Benninghoff, W. S. 1987. Environmental influences on deposition of airborne particles. In: Boehm G, Leusner RM (eds) Advances in Aerobiology. Proceeding of the 3rd International Conference on Aerobiology. Birkhäuser, Basel. pp 11-18.

Charles, B., Fredday, P., Julie, L., Frank, H., Jay, P. 2001. The effect of temperature, relative humidity and rainfall on airborne ragweed pollen concentrations. Aerobiologia 17:61-68.

Charlesworth, D. 1993. Why are unisexual flowers associated with wind pollination and unspecialized pollinators? Am Nat141:481-490.

Claypoole, S. T., Slesnick, U. L. 1983. The beauty and biology of pollen. American Biology Teacher 45:366370.

Crane, P. R. 1986. Forms and function in wind dispersed pollen and spore;form and function Ed. S. Blackmore and I.K. Ferguson London: Academic press, pp179 202.

Dale, P. J., Clarke, B., Fontes, E. M. 2002. Potential for the environmental impact of transgenic crops. 20: Nature Biotechnology 567-574.

Erdtman, G. 1960. The acetolysis method, A Revised Description, Svensk Botany Tidskr., 51: 561-567.

Feher, Z., Jarai-Komlodi, M. 1996. Relationship between airborne ragweed pollen concentration and the macrosynoptic weather types in Budapest, Hungary. Ann. Agric. Environ. Med. 3:121-126

Gregory, P. H. 1978. Distribution of airborne pollen and spores and their long distance transport. Pure Appl Geophys, 116:309-315

Hasnain, S. M., Fatima, K., Al-Frayh, A., Al-Sedainy, S. 2005. One-year pollen and spore calendars of Saudi Arabia Al-Khobar, Abha and Hofuf. Aerobiologia 21:241-247.

Kaplan, A. 2004. Airborne pollen grains in Zonguldak, Turkey, 2001-2002. Acta Bot. Sin. 46:668-674.

Levetin, E. 1991. Identification and concentration of airborne Basidiospores. Grana 30:123-128.

Lighthart, B., Spendlove, J. C., Akers, T. G. 1979. Sources and characteristics of air borne materials. Factors in the production, release and viability of biological particles In: Edmonds R. L. (Ed) Aerobiology. The ecological systems approach. Dowden Hutchinson \%Ross, Stroudsburg, pp. 11-84.

McDonald, M. S., O’Driscoll, B. J. 1980. Aerobiological studies based in Galway: A comparison of pollen and spore counts over two seasons of widely different weather conditions. Clin. Exp. Allergy 10:211-215
Molina, R. T., Palacios, I. S., Rodriguez, A. F., Munoz, J. T., Corchero, A. M. 2001. Environmental factors affecting airborne pollen concentration in anemophily species of Plantago. Ann. Bot. 87:1156-1158.

Mc Donald M. S. 1979. The effect of meteorological conditions on the concentration of airborne pollen over an estuarine area on the west coast of Ireland. Pollen spores 21:233-238.

Mc Donald, M. S. 1980. Correlation of airborne grass pollen levels with meteorological. Grana, 19: 53-56.

Murray, M. G., Sonaglion, M. I., Villamil, C. B. 2002. Annual variation of airborne pollen in the city of Bahia Blance, Argentina. Grana 41:183-189.

Newnham, R. M. 2001. Aeropalynology and global warming, pp. 570. In: Goodman, D. K. and R. T. Clarke (Eds.). Proceedings of the IX International Palynological Congress, Houston, Texas, U.S.A., 1996; American Association of Stratigraphic Palynologists Foundation.

Nitius, D. S. 2004. Intradiurnal fluctuation of pollen in La Plata, Argentina. PartI, herbaceous pollen types. Aerobiologia, 20: 69-74.

Njokuocha, R. C. 2006. Airborne pollen grains in Nsukka, Nigeria. Grana, 45(1): 73- 80

Njokuocha, R. C., Osayi, E. E. 2005. Airborne pollen and spore survey in relation to allergy and plant pathogens in Nsukka, Nigeria. Bio-Research, 3(1): 77-84.

Paloma, C., Carmen, G. A. 2004. Purificacion and D. Eugenio Airborne pollen records response to climatic conditions in arid areas of the Iberian Peninsula. Environ. Exp. Bot. 52: 11-22.

Sarjeant, W. A. S. 2002. As chimney-sweeps, come to dust': a history and out: some major contributions to geology in the twentieth century. Geological Society (London) Special Publication no. 192.

Subiza, J. J., Masiello, M., Subiza, J. L., Jerez, M., Hinojosa, M., Subiza, E. 1992. Prediction of annual variations in atmospheric concentration of grass pollen. A method based on meteorological factors and grain crop estimates. Clin. Exp. Allergy 22:540-546.

Tejera, L., Beri A. 2005. First volumetric airborne pollen sampling in Montevideo City, Uruguay. Aerobiologia 21:33-41. 